\title{
Um rei encoberto debaixo dum santo: sebastianismo no "sermão a São Sebastião", de padre Antônio Vieira
}

Adriano Lima Drummond Universidade de São Paulo

Fede è sustanza di cose sperate e argomento de le non parventi e questa pare a me sua quiditate. ${ }^{1}$ Dante Alighieri, Paraíso, "Canto XXIV"

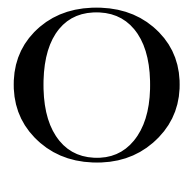

“sermão" ou "panegírico a São Sebastiāo", de padre Antônio Vieira, pregado na Bahia a 20 de janeiro de 1634, é um dos mais interessantes textos dentro da extensa obra parenética do jesuíta. Esse interesse se deve a, dentre outros fatores, conter o panegírico uma significação textualmente não explícita, arquitetada por um conjunto de elementos alusivos, os quais, uma vez tendo o ouvinte/leitor plena consciência deles, tornam a palavra 'Sebastião' e o universo textual que a envolve uma referência tanto ao santo, como está claro, quanto ao penúltimo rei português da dinastia de Avis, D. Sebastião, cuja figura postmortem constituiu-se objeto de uma crença coletiva, de caráter messiânico, importante e longeva no cenário luso-brasileiro: o sebastianismo. De fato, a penetração sócio-cultural do sebastianismo foi de tal ordem, que - num período como o das primeiras décadas do século XX, já bem longe do ano

\footnotetext{
1 "Fé é substância das coisas esperadas, /e argumento das que não são aparentes; / esta me parece a sua essência." (tradução nossa)
} 
da morte de D. Sebastião, sucedida em 1578 - encontramo-lo como nevrálgica motivação místico-poético-nacionalista da obra ortônima de Fernando Pessoa, conforme vemos no livro Mensagem e em escritos de cunho político, com passagens como esta:

No sentido simbólico D. Sebastião é Portugal: Portugal que perdeu a sua grandeza com D. Sebastiáo, e que só voltará a tê-la com o regresso dele, regresso simbólico - como, por um mistério espantoso e divino, a própria vida dele fôra simbólica - mas em que não é absurdo confiar. ${ }^{2}$

Neste artigo, analisaremos o acima referido sermão de Vieira, um dos mais importantes textos do autor no que se refere ao período dentro do qual expressou crenças sebastianistas, isto é, até 1640 , quando a Restauração dá fim aos 60 anos da União Ibérica e começo ao Portugal governado pela dinastia portuguesa de Bragança. Ao contrário de um outro texto atribuído ao jesuíta lisboeta, o "Discurso em que se prova a vinda do Senhor Rei D. Sebastião", o "Sermão a S. Sebastião", como já dissemos, constitui uma espécie de manifesto sebastianista velado e nossa análise focalizará os recursos de que se valeu padre Antônio Vieira para aludir ao rei português, além de pinçar elementos do imaginário místico-político e cultural da época, elementos do contexto histórico que envolvem o sebastianismo no momento de pregação desse sermão.

${ }^{2}$ PESSOA, 1978, p. 202. No século XIX, o sebastianismo já havia sido tematizado como espécie de caráter da alma lusitana, em sentido positivo ou negativo, por nomes canônicos da literatura portuguesa. A título de exemplo, fizeram-no Almeida Garrett, em Frei Luís de Sousa, Antônio Nobre, em O Desejado, e Eça de Queirós, em $A$ cidade e as serras. Não podemos deixar aqui de citar o nome do historiador oitocentista Oliveira Martins, quem, nas palavras de Eduardo Lourenço, viu no sebastianismo "manifestação típica do nosso [dos portugueses] comportamento nacional elevado a signo dele", e, assim, "Do que era um fenômeno extravagante ou uma aberração sem lugar no discurso histórico, Oliveira Martins fez um mito cultural de ressonância incomparável”. (LOURENÇO, 1999, p.47) O itálico é do autor citado e neste artigo sempre o será; negritos serão nossos. 
Padre Antônio Vieira, no "Panegírico a S. Sebastião", parte de um excerto do Evangelho de S. Lucas, os versículos 20 a 22 do capítulo 6: "Beati pauperes: quia vestrum est regnum Dei. Beati qui nunc esuritis: quia saturabimini. Beati qui nunc fletis: quia ridebitis. Beati eritis cum vos oderint homines", cuja tradução seria: "Bem-aventurados vós, os pobres, porque é vosso o Reino de Deus. Bem-aventurados vós que agora tendes fome e sede, porque sereis saciados. Bem-aventurados vós que agora chorais, porque rireis. Bem-aventurados vós que sois perseguidos pelo ódio dos homens". O jesuíta começa por dizer, basendo-se na interpretação dessas palavras de Cristo transcritas pelo evangelista, que a bem-aventurança não existe apenas no Céu, como muitos acreditam, mas existe também na terra, uma vez que - profere Jesus - os pobres, os que têm sede e fome, os que são alvos de ódio e perseguição - não os havendo no Céu, mas apenas na terra - são bem-aventurados. A cada um desses tormentos terrestres Vieira aponta um dote celestial correspondente:

A pobreza, que nos alivia do peso e embaraço das coisas da terra, responde ao dote da agilidade: Beati pauperes. As lágrimas, que entre as sombras da tristeza são os claros do alívio e consolação, respondem ao dote da claridade: Beati qui lugent. A fome e a sede que atenua e adelgaça a quantidade grosseira do corpo responde ao dote da sutileza: Beati qui nunc esurit. A paciência generosa, com que os ódios e perseguiçôes se fazem menos sensíveis, responde ao dote da impassibilidade: Beatis estis [sic] cum vos oderis homines. Tão parecidos são como isto os espíritos bem-aventurados da terra com os corpos bem-aventurados do céu!

Mas, afinal, qual seria a diferença entre a bem-aventurança no céu e a bem-aventurança na terra? A resposta é que a primeira é "descoberta e visível", ao passo que a segunda é "invisível e encoberta" debaixo de cada um dos tormentos assinalados no trecho do Evangelho. ${ }^{4}$ Em seguida, eis

${ }^{3}$ VIEIRA, 1951, p. 340. (Atualizei a ortografia do texto vieiriano desta edição, conforme as regras gramaticais brasileiras vigentes.)

${ }^{4}$ VIEIRA, 1951, p. 340. 
precisamente declarado o tema do sermão: "[...] resumindo o meu discurso só a duas palavras, todo o assunto dele será este: Sebastiāo, o Encoberto." ${ }^{5}$

O romano Sebastião, que viveu no século III, serviu como militar ao imperador Diocleciano e tinha como dever perseguir os cristãos. Tendose convertido ao cristianismo, Sebastião procura burlar o cumprimento de suas funçôes. Denunciada sua desobediência, é condenado a morrer alvejado por flechas. Punido e tomado como morto, seus algozes entregam-lhe o corpo a Irene, quem, posteriormente, descobre que aquele homem milagrosamente não havia morrido e cuida de suas feridas. Após algum tempo, Sebastiáo vai ao encontro de Diocleciano, para repreendê-lo por sua perseguição aos cristãos. O imperador, no início espantado com o aparecimento de quem julgava morto, trata de mais uma vez puni-lo, ordenando que seus soldados o espanquem até à morte e, assim, de fato, o santo vem a falecer.

Segundo Vieira, São Sebastião teria sido encoberto na vida e na morte, "porque encobriu a realidade da vida debaixo da opinião da morte" e "encobriu a aparência da morte debaixo da realidade da vida", e teria sido encoberto também na fé e nas obras, "porque encobriu a verdade da fé com a política das obras" e "encobriu a política das obras com a dissimulação da fé" ${ }^{6}$ Quanto ao fato de julgarem o santo morto, quando na verdade estava vivo, o sermonista se reporta ao exemplo de Jacó, que enganadamente acreditou, tendo visto a túnica de seu filho José ensangüentada, que este tivesse morrido e, dada a ausência de seu cadáver, sido ainda devorado por feras. O jesuíta, dirigindo-se a Jacó como interlocutor, no intuito retórico de destacar o engano pelo qual se deixou levar o personagem bíblico, referese a outro exemplo, o do quase sacrifício de Isaac pelas mãos do próprio pai, Abraão, a mando de Deus. Alguém que fechasse os olhos entre o instante em que Abraão prepara o golpe mortal contra Isaac e o instante em que há cinzas sobre a pedra sobre a qual estava Isaac, acreditaria - também enganadamente - que as cinzas seriam do filho sacrificado pelo pai;

\footnotetext{
5 VIEIRA, 1951, p. 341.

${ }^{6}$ VIEIRA, 1951, p. 341.
} 
entretanto, tratava-se de cinzas do cordeiro que, graças a intervenção de um anjo, também a mando de Deus, deveu ocupar o lugar de Isaac no sacrifício. Após demonstrar como "se equivoca a morte com a vida em um só abrir e fechar de olhos" ", no episódio de Isaac e Abraão, Vieira, ainda mantendo Jacó como interlocutor no sermão, pergunta-lhe por que não crer que José esteja vivo e o sangue na túnica seja de um animal, assim como as cinzas não eram de Isaac, mas de um cordeiro, principalmente tendo em vista as promessas de Deus de que José é predestinado a um futuro grandioso até então não cumprido. Entretanto, pondera o sermonista:

Todos estes motivos, tão fortes e tão bem fundados, tinha Jacó para não crer que José fosse morto; mas nem razões, nem conveniências, nem profecias, nem exemplos, nem coisa alguma do mundo era bastante para aliviar um momento de sua tristeza: nem a o persuadir ou alentar, a que admitisse alguma melhor esperança. Tão certo, tão firme, tão desenganado estava de que José era morto [...]. ${ }^{8}$

O que, na verdade, teria acontecido com José, Vieira passa a contar: tendo sido por Deus "escolhido e reservado para restaurador do mundo", ${ }^{9}$ José encontrava-se no Egito, de onde, após ter sofrido diversas penas, como ser aprisionado, vendido e quase morto, tornara-se, em cumprimento de seu destino profetizado, faraó. É que "a Providência Divina tinha determinado que ele [José] estivesse tantos anos encoberto sem saberem dele os de sua casa nem os de sua nação [Canaã]". ${ }^{10} \mathrm{O}$ caso de José - crido morto em sua terra, mas vivo no Egito - é comparado, logo em seguida, ao de Sebastião; o caso deste mais surpreendente, pois que o romano foi dado por morto em Roma e na mesma cidade continuava vivo. Vieira ressalta que, em tal aspecto, o sucedido com Sebastião (embora ele não tivesse propriamente ressuscitado, apenas sobrevivido às flechadas) assemelha-se ao sucedido com Jesus:

\footnotetext{
7 VIEIRA, 1951, p. 344.

${ }^{8}$ VIEIRA, 1951, p. 344.

${ }^{9}$ VIEIRA, 1951, p. 345.

10 VIEIRA, 1951, p. 345.
} 
No mesmo Horto do Sepulcro falava Cristo com a Madalena; no mesmo caminho de Emaús falava Cristo com os dois discípulos; e bastava um disfarce de hortelão, ou de peregrino, para que em Cristo se encobrisse a realidade de vivo, e na Madalena e nos Discípulos se continuasse a opinião de morto. ${ }^{11}$

Essa equivocada opinião de Madalena e dos discípulos durante os três dias após a crucificação de Jesus recordará a Vieira os três dias durante os quais os marinheiros de Jope tiveram Jonas por morto, após verem-no engolido por uma baleia. Nesse ponto, temos tal consideração:

Que coisa era aquela grande baleia no meio do mar, senão uma ilha errante, em que ninguém podia tomar porto, que já aparecia, já desaparecia? Mas encoberto Jonas nesta ilha encoberta, por mais que a opinião o tenha por morto, como passaram os dias e as noites da profecia de Cristo, ele desembarcará vivo, e com assombro, nas praias de Nínive. ${ }^{12}$

Esse mesmo milagre se passará com Sebastião, que, após ter sido alvejado por numerosas flechas, e tido por morto durante um certo tempo, virá a aparecer vivo perante o imperador Diocleciano.

Os casos de Isaac, de José, de Cristo e de Jonas - associados entre si e ao caso de Sebastião - funcionam nesse passo inicial do sermão como exemplificação do que padre Antônio Vieira denomina "realidade da vida debaixo da opinião da morte". No passo seguinte, o jesuíta discorre sobre como o santo romano "encobriu também a aparência da morte debaixo da realidade da vida", ${ }^{13}$ ao receber, por ordem de Diocleciano, um outro tão cruel e sanguinário castigo que, com efeito, parecerá morto aos olhos dos presentes, mas ainda assim continuará vivo (não física, mas espiritualmente em bem-aventurança). Tal segundo milagre ocorrido com Sebastião se explica com tais palavras:

${ }^{11}$ VIEIRA, 1951, p. 345-346.

12 VIEIRA, 1951, p. 346.

${ }_{13}$ VIEIRA, 1951, p. 346. 
Esta é a excelência da morte de quem morre em Deus, e por Deus, e para Deus. As outras mortes são descobertamente o que parecem: parecem mortes, e são mortes: a morte de quem morre por Deus, e para Deus, não é o que parece, é uma aparência de morte debaixo da realidade da vida. ${ }^{14}$

Apenas os sábios, dirá o sermonista amparado por São Paulo, percebem a falsidade da morte dos santos, sabem ver a realidade em desprezo das aparências, nas quais se fiam exclusivamente os néscios. A idéia de morte em, por e para Deus constitui chave para compreendermos o que seja encobrir 'a aparência da morte debaixo da realidade da vida'. Não haveria morte para quem morre dessa forma senão aos olhos dos néscios; os sábios entenderiam que os santos, como Abraão, Isaac, Jacó só morrem aparentemente, mas na realidade teriam vida mesmo após a morte, como é o caso de Sebastião em seu segundo castigo. Aqui, portanto, se confundem as duas espécies distintas de morte aparente pelas quais passa o santo romano. Na primeira espécie ('realidade da vida encoberta debaixo da opinião da morte'), não há morte física, pois, ao contrário do que todos acreditam, Sebastião vive em sua materialidade corpórea. $\mathrm{Na}$ segunda espécie ('aparência da morte encoberta debaixo da realidade da vida'), há, sim, morte física; o que não há é a morte do espírito condenado ao Inferno, mas a vida espiritual de bem-aventurança no Céu, da qual gozariam Abraão, Isaac, Jacó e, depois do segundo castigo imposto pelo imperador, São Sebastião.

Padre Antônio Vieira passa a discorrer sobre as duas últimas combinações que sintetizam a vida votada a Cristo de São Sebastião: o de ter encoberto "a verdade da fé com a política das obras" e "a política das obras com a dissimulação da fé". ${ }^{15}$ Quanto à primeira destas sentenças, Sebastião - destaca o sermonista -, embora parecesse servir ao Império Romano, era, na verdade, um servidor de Cristo, ocultando este serviço com o fim de melhor servir a Deus como cristão. Vieira evidencia essa necessidade de encobrimento

${ }^{14}$ VIEIRA, 1951, p. 347.

15 VIEIRA, 1951, p. 350. 
com dois exemplos: 1) o de José e Nicodemo, desconhecidos como seguidores de Cristo, mas os únicos a amparar-lhe o corpo crucificado, o que não fizeram os conhecidos apóstolos Pedro, André e João. $\mathrm{O}$ sermonista esclarece o fato: "Ninguém era mais amigo, nem mais animoso que João; mas João não se atreveu a procurar a licença de Pilatos, como José; porque em João a fé e a amizade declarada era suspeitosa, e em José a fé e a amizade encoberta era efetiva." ${ }^{16}$ 2) Outro exemplo é o de Husai, que, sendo o "maior confidente e mais fiel amigo que então tinha Davi", foi enviado por este a servir Absalão (maior inimigo de Davi), na mais sábia medida tomada, segundo o jesuíta, pois "muito maiores serviços lhe podia fazer a fé de Husai encoberta em casa de seu inimigo, do que a fé do mesmo Husai declarada em sua própria casa". ${ }^{17}$ Nesse caso, Vieira chega a explicitar uma correspondência que estrutura todo o sermão:

Quem é Davi, senão Cristo? Quem é Absalão, senão Diocleciano? Quem é Husai, senão Sebastião? Mete Cristo a Sebastião, seu maior confidente, em casa de Diocleciano, seu inimigo, para que ali obre a sua fé encoberta muito mais do que pudera fazer fora dali declarada. ${ }^{18}$

Quando chega o momento de desenvolver sobre a quarta e última das sentenças referentes à vida de Sebastião, o ter encoberto 'a política das obras com a dissimulação da fé', padre Antônio Vieira alega falta de tempo (que "sempre é forçoso faltar, onde o sujeito é maior que tudo o que se pode dizer" ${ }^{19}$ ) e conclui o panegírico com um pedido ao santo para que acuda os pobres, os que choram, os que têm fome e sede e os que são perseguidos pelo ódio dos homens do reino. Tais palavras fecham o sermão: "Desta maneira, Santo glorioso, por meio de vosso amparo conseguiremos a bem-aventurança encoberta desta vida, até que por meio da vossa

\footnotetext{
${ }_{16}$ VIEIRA, 1951, p. 352.

17 VIEIRA, 1951, p. 352.

18 VIEIRA, 1951, p .353.

${ }^{19}$ VIEIRA, 1951, p. 353.
} 
intercessão alcancemos a bem-aventurança descoberta da outra: Ad quam nos perdurat, etc" ${ }^{20}$

Prescinde dizer que o leitmotiv do panegírico é a idéia de 'encoberto', ou seja, de algo que verdadeiramente existe, porém não se expõe à vista, sendo apenas percebido ou sentido pela fé e pela sabedoria-aquela e esta, está claro, implicadas uma na outra. A idéia de 'encoberto', exclusiva do mundo terreno (no mundo celestial, tudo é desvelado e visível) e marcada pela antítese entre aparência e realidade, coloca-se de duas maneiras no texto. A primeira corresponde ao que o jesuíta denomina encobrir 'a realidade debaixo da opinião da morte' e encobrir 'a aparência da morte debaixo da realidade da vida'. A aparência aqui se entende como engano de quem, descrente ou mesmo néscio, vê e faz inferências errôneas, desacreditando das profecias. Este é o caso de Jacó frente à túnica ensangüentada de seu filho José, da imaginada testemunha do quase sacrifício de Isaac pelas mãos de Abrãao, dos marinheiros ao avistarem Jonas ser engolido por uma baleia etc; exemplos que se equivalem ao que se sucedeu com Irene e Diocleciano, convictos da morte de Sebastião após este ter sido alvejado pelas flechas. Nesse passo, Vieira focaliza a aparência do ponto de vista de quem observa. A segunda maneira pela qual aparece a idéia de 'encoberto' corresponde ao encobrir 'a verdade da fé com a política das obras' e encobrir 'a política das obras com a dissimulação da fé'. Aqui a aparência entende-se como necessidade, motivo de quem aparenta, atitude sábia por meio da qual se pode melhor realizar boas obras. É o caso de José e Nicodemo, desconhecidos seguidores de Cristo, mas que por isso mesmo puderam melhor amparar o corpo crucificado do Divino Mestre, caso de Husai, que melhor serve a Davi servindo ao maior inimigo deste, Absalão; exemplos que se equivalem ao que fazia Sebastião, que, para melhor praticar seus atos piedosos, ocultou sua fé como servidor do imperador Diocleciano. Nesse segundo passo, Vieira focaliza a aparência do ponto de vista de quem é o observado ou de quem aparenta. Tal antítese entre realidade e aparência já está implicada na passagem do Evangelho de São Lucas, ponto de partida do sermão. Não

20 VIEIRA, 1951, p. 354. 
apenas no Céu há bem-aventurança, começa Vieira dizendo; a bem-aventurança ocorre também na Terra, mas apenas para os que são pobres, os que choram, os que têm fome, os que são perseguidos pelo ódio dos homens. É necessária, portanto, essa desventura (aparente) para ser bem-aventurado (efetivamente). Porém, somente os sábios compreendem essa necessidade.

No panegírico, padre Antônio Vieira associa a condição de 'encoberto' do santo romano a outros casos, extraídos das Escrituras, construindo com isso uma rede tipológica. De um modo - relacionado com a Providência Divina e inserido no foco do observador, acima referido -, foram também 'encobertos', antes de São Sebastião, Isaac, José (filho do Jacó), Cristo e Jonas; todos estes, como o santo homenageado por Vieira, teriam encoberto a realidade da vida debaixo da opinião da morte' e/ou encoberto a 'aparência da morte debaixo da realidade da vida'. De outro modo relacionado com a sabedoria pessoal, humana (da qual, é certo, não se exclui a intercessão da Providência Divina e que se insere no foco do observado, também acima referido) -, foram 'encobertos', como São Sebastião, José (seguidor de Cristo), Nicodemo e Husai, cuja fé em Jesus ou fidelidade ao Bem (representado por Davi) precisaram ser ocultas no intuito de melhor realizar boas obras. Com base nessa analogia tipológica, típica dos textos religiosos da época, Vieira assinala como os exemplos bíblicos prefiguram os feitos de São Sebastião (ter sabiamente servido a Deus, ocultando sua fé, e sobrevivido a uma punição mortal). As hagiografias, portanto, compartilhariam algo daquele caráter das Escrituras, as quais "não são nunca, para os cristãos, coletâneas de imagens, mas relatos de fatos que figuram em sua história real a história futura”. ${ }^{21}$

Mas há um outro plano de significação que, embora não explícito, não pode ser desprezado ou despercebido sem prejuízo de uma compreensão completa do texto vieiriano. Se, num primeiro plano, as passagens das Escrituras funcionam como espécie de ratificação do que a hagiografia narra sobre o santo romano, num segundo plano, tanto as passagens bíblicas quanto as hagiográficas funcionam como espécie de ratificação do discurso

${ }^{21}$ PÉCORA, 1994, p. 222. 
sebastianista, que está velado, ou (para empregarmos termo caro ao contexto) 'encoberto' nesse sermão de Vieira. Assim, nessa cadeia de associações - Isaac, José (filho de Jacó), Cristo, Jonas e José (seguidor de Cristo), Nicodemo e Husai - com o santo romano, há um último e implícito termo associado: D. Sebastião, o monarca português da dinastia de Avis, morto e desaparecido na batalha de Alcácer Quibir, ocorrida em 1578, mas acreditado pelos sebastianistas vivo e escondido, aguardando o momento certo para retornar à pátria como messias salvador.

D. Sebastião nasceu a 20 de janeiro de 1554 , ansiosamente esperado pelo reino havia duas décadas, em decorrência de incertezas relativas à sucessão dinástica. Atribuíram-lhe, assim, o epíteto de 'O Desejado'. Tornase rei aos quinze anos, e cedo procura resgatar a antiga glória de um país política e economicamente bastante enfraquecido e desprestigiado, mas que se fundara a partir de heróicas batalhas contra mouros e espanhóis e desbravara mares nunca dantes navegados e construíra enorme império ultramarino com territórios em Europa, África, Ásia e América, figurando - até princípio do século XVI - entre as principais nações do mundo. Numa espécie de cruzada moderna, o monarca, fervoroso católico, acompanha, aos vinte e quatro anos, seu exército rumo a Alcácer Quibir, na região atual do Marrocos, no intuito de, vencendo os árabes infiéis, retomar a presença portuguesa e cristã no norte da África. Sua inexperiência militar e o contingente de soldados numericamente muito inferiores levaram os portugueses a fragorosa derrota na batalha contra os chefiados por Moulay Malik. O próprio D. Sebastião desaparece, ao que tudo indica, morto em combate. O rei, solteiro e casto, deixava sem herdeiro direto o trono. Assume-o seu tio-avô D. Henrique. No entanto, o problema da sucessão permanecia, uma vez que D. Henrique era cardeal (não poderia, sem permissão papal, ter filho), já contava 66 anos e se encontrava com uma saúde bastante debilitada. Sem alcançar a licença para casar-se, falece em 1580. Já maquinando a posse da coroa portuguesa desde pelo menos o reinado do sobrinho D. Sebastião, o astuto rei espanhol D. Filipe II (parente próximo deste rei português) concretiza seus intuitos, auxiliado pela invasão por seu exército do país vizinho. Começava assim a União Ibérica, que duraria até 1640 . 
As controvérsias em torno do fim de D. Sebastião na batalha de Alcácer Quibir, em agosto de 1578, possibilitaram surgir a crença de que o rei pudesse não estar morto. Entre os que retornaram da campanha na África, "nenhum súdito poderia [ter assistido] à morte do soberano em combate sem se entregar ao inimigo antes dele", pois "Confessar ter sido testemunha de tal desventura era não só pessoalmente vergonhoso como ofendia a todo o corpo do reino e desonrava a todos os portugueses". ${ }^{22} \mathrm{Tal}$ crença sedimentou as bases do que se denominaria sebastianismo, cujas condiçôes de surgimento Hernâni Cidade e Carlos Selvagem explicitam sinteticamente nestes termos:

[...] as condiçóes da vida nacional determinavam a necessidade de uma esperança como de redenção colectiva, sobretudo para muitos portugueses educados na crença da sobrenaturalidade de muitos episódios da nossa história, convictos de que, pelo menos desde Ourique, tinha Deus tomado Portugal como seu povo eleito e assim o exprimira o diálogo de Jesus com D. Afonso Henriques nas vésperas da batalha. ${ }^{23}$

A catástrofe de Alcácer Quibir e, dois anos após, o início da União Ibérica contrariavam os sonhos do reino lusitano, onde, nos seiscentos, já eram bastante conhecidas narrativas quatrocentistas que noticiavam um milagre ocorrido às vésperas da vitória em Ourique, a que se seguiu a fundação de Portugal. D. Afonso Henriques, futuro primeiro rei português,

${ }^{22}$ HERMANN, 1998, p.131.

${ }^{23}$ CIDADE e CARLOS, 1972, p.129-130. Eduardo d'Oliveira França propõe explicação de ordem psico-patológica-epocal para o fenômeno: "No fundo subconsciente, aquelas almas saudosistas e desalentadas expressavam no sebastianismo um desejo barroco de morte". (FRANÇA, 1998, p.246) Joel Serrão, por sua vez, em abordagem de contornos sociológico-marxistas, pergunta: "E não será possível apreender nos motins sebastianistas e nas 'alteraçōes' do século XVII esse rumor surdo da miséria do povo português? Não será o sebastianismo, ao fim e ao cabo, uma das formas desse protesto surdo e impotente, como vamos insinuando?" (SERRÃO, 1973, p.27) 
teria avistado no céu a imagem de Jesus Cristo crucificado, vaticínio não só do futuro glorioso daquele reino que, dali a pouco, surgiria, mas também de ser esse reino eleito por Deus e que haveria de consumar o Quinto Império. ${ }^{24}$ Como se sabe, o Milagre de Ourique só veio a ser desmentido, no século XIX, por Alexandre Herculano, com base no fato de que o primeiro relato do aparecimento de Cristo a D. Afonso Henriques antes da batalha sucedida em 1139 é uma crônica de 1419, ou seja, cerca de 300 anos após o suposto episódio miraculoso. Isso levou o historiador e escritor português a concluir tratar-se de acréscimo fantasioso, nada extraordinário numa época em que acontecimentos sobrenaturais

${ }^{24}$ A idéia de Portugal como Quinto Império, muito importante para o sebastianismo, e para a obra parenética e profética vieiriana, deriva de interpretações heterodoxas do segundo capítulo do "Livro de Daniel", que, a propósito, renderiam ao jesuíta problemas sérios com a Inquisição. $\mathrm{O}$ excerto bíblico se refere a um incômodo e enigmático sonho do rei babilônico Nabucodonosor, que o profeta caldeu Daniel, pela graça divina, adivinha e interpreta. Uma estátua enorme e esplendorosa; tem a cabeça de ouro, o peito e os quadris de bronze, as pernas de ferro e os pés parte de ferro e parte de barro. De repente, uma pedra cai em cima dos pés da estátua, destruindoa completamente e depois crescendo até ocupar toda a Terra - eis o sonho de Nabuconosor, a quem Daniel diz significar a sucessão de cinco reinos: o primeiro, o da Babilônia, simbolizado pela cabeça de ouro; o segundo, pelos membros de bronze; o terceiro, pelas pernas de ferro, o quarto - um reino dividido - e, por isso, simbolizado por pés feitos de ferro e de barro, e, enfim, o último reino, eterno, que a pedra, destruidora de toda a estátua, representa. Segundo a hermenêutica medieval, a passagem bíblica profetizava vir a suceder-se ao império assírio o persa, a este o grego e ao grego o romano, que, com efeito, tornou-se um império dividido, conforme a interpretação de Daniel quanto aos pés da gigantesca estátua sonhada por Nabucodonosor. A pedra, em coerência com toda a simbologia cristã, significaria o próprio Cristianismo, fé religiosa que se expandiria pelo mundo inteiro como Verdade Suprema e Jesus, o verdadeiro rei dos homens. Essa meta-interpretação - hermeneutas da Idade Média a esclarecer significados de significados antes esclarecidos por Daniel - ganha ela mesma outra camada interpretativa na mítica nacionalista portuguesa, a partir do século XV. 
povoavam o imaginário e a visão de mundo européia. Aliás, no ano de 1419, estamos em pleno início do expansionismo ultramarino português, tendo ocorrido a conquista de Ceuta apenas quatro anos antes. Esse ambiente de fervor místico e entusiasmo nacionalista em Portugal explica a popularidade das trovas proféticas de Bandarra, o Nostradamus lusitano, que viveu na primeira metade do século XVI e vaticinava, em linguagem hermética e simbólica, a vinda de um rei encoberto que iria trazer uma era de infinita prosperidade à pátria e ao mundo. De fato, as profecias de Bandarra foram muito difundidas (impressas e oralmente) e foram objeto de várias interpretaçōes que tanto procuravam prever o futuro do reino quanto comprovar nos acontecimentos presentes os propósitos divinos. Também foram de fundamental importância para as expectativas e profecias sebásticas, quando muitos portugueses se ressentiam da União Ibérica e esperavam uma transformação política de ordem providencial, ou, mais especificamente, o retorno de D. Sebastião a Portugal na qualidade de messias salvador, ${ }^{25}$

${ }^{25} \mathrm{O}$ caso de D. Sebastião, morto em batalha contra mouros, parece especialmente promover uma associação com essa idéia de messias ou de vice-Cristo, para utilizar termo empregado pelo próprio Vieira. A esse propósito, reportamonos a trecho de "São Francisco de Assis na Comédia de Dante", análise de E. Auerbach, no qual é dito: "Suceder ou imitar a Cristo é, para todos os cristãos, uma meta nitidamente traçada, como se pode constatar em muitos trechos do Novo Testamento. No primeiro século da Igreja militante, o testemunho dado pelo sangue dos mártires mostrava que, a sucessão devia ser realizada não apenas moralmente, pela obediência aos mandamentos e pela imitação das virtudes, mas integralmente, através de sofrimentos iguais ou de um martírio semelhante. Mesmo após esse período, a tentativa de seguir integralmente os passos de Cristo, de imitar seu destino, ainda era objeto de uma procura esforçada; de tal modo que até a morte de um herói numa batalha contra os infiéis era interpretada como uma forma de sucessão." (AUERBACH, 1997, p.78) Além dessa forma de sucessão que se encontra em D. Sebastião, há de se destacar também seu fervor católico e firme postura celibatária. Não sendo, entretanto, objetivo desse artigo de abordar as causas do sebastianismo (algo muito acima das possibilidades de um artigo), não avançaremos aqui nessa questão. 
para, então, promover, em seu governo, uma era de infinita prosperidade, já anunciada no Milagre de Ourique.

Facilmente entendemos o motivo precípuo de padre Antônio Vieira não explicitar o caráter sebastianista de seu panegírico a São Sebastião. No momento em que o prega, em 1634, a dinastia filipina governava o reino português e, naturalmente, os Filipes espanhóis indispunham-se contra o sebastianismo. A propósito, casos anteriores de falsos D. Sebastióes tiveram triste fim, com severa punição dos falsários e dos principais envolvidos. De fato, o sebastianismo surge motivado por um sentimento anticastelhano e visão sobre a União Ibérica como ato de usurpação do trono português. Desde D. João de Castro - o primeiro a escrever obra, publicada em 1602, na qual anunciava o retorno de D. Sebastião -, o sebastianismo foi ganhando adeptos entre a cultura letrada, especialmente membros da Companhia de Jesus.

Não nos cause espanto o fato de que jesuítas, no Portugal do século XVII, expressem crenças condenáveis (e, muitas vezes, condenadas) pela ortodoxia católica. Farta bibliografia informa como nos seiscentos fé e crendice se conciliavam ${ }^{26}$ tanto entre as camadas mais populares quanto entre os religiosos, especialmente os da Companhia de Jesus. Segundo Eduardo d'Oliveira França, em seu clássico estudo Portugal na época da Restauração:

Em quase todas as agitaçôes sebastianistas estiveram envolvidos padres e as trovas de Bandarra eram guardadas por prelados. Nesse profetismo parte enorme coube à Companhia de Jesus, a guardiã da ortodoxia tomista e do espírito da Reforma Católica. ${ }^{27}$

Casos específicos e destacáveis de jesuítas comprometidos com crenças heterodoxas foram o de Manuel da Veiga, que, em 1625, "publicava em Portugal a Vida de Simão Gomes, sapateiro contemporâneo dos reinados de d. João III e d. Sebastião, que ficou conhecido pelo codinome de Sapateiro

${ }^{26}$ FRANÇA, 1997, p. 237.

${ }^{27}$ FRANÇA, 1997, p. 239. 
Santo e não raro associado à trajetória profética do célebre Bandarra" ${ }^{28} \mathrm{e}$ o de João de Vasconcelos, que, na década de 1640, escreverá obra na qual, a partir de interpretações das trovas de Bandarra, anunciará D. João IV, o primeiro rei da nova dinastia portuguesa de Bragança, como o 'Encoberto', em vez de D. Sebastião ${ }^{29}$ (assim como o fará também padre Antônio Vieira, após vir a ter notícia da Restauração, ocorrida em 1640)..$^{30}$

Posto isso, entendemos tanto como Vieira, membro de uma ordem religiosa, expressa crenças heterodoxas (no caso, sebásticas) quanto a razão de o jesuíta lisboeta não torná-las explícitas em seu sermão - no que também não estava isolado; informa Jacqueline Hermann:

Se Felipe II enfrentou uma resistência mais explícita e direta, motivada pelos debates sobre a sucessão [no trono lusitano], [...] os reinados de seus sucessores não deixaram de defrontar com a oposição dos religiosos disseminada pelas pregações dominicais e nos dias santos. O que se observa é uma maior sofisticação das mensagens, o apuro das metáforas, a utilização cada vez maior de imagens bíblicas, aparentemente distantes [...]. ${ }^{31}$

Todos esses elementos elencados por Hermann ${ }^{32}$ estão presentes no "panegírico a São Sebastião", além de um recurso alusivo de fundamental

${ }^{28}$ HERMANN, 1998, p. 219.

${ }^{29}$ Cf FRANÇA, 1998, p. 250.

${ }^{30} \mathrm{Em}$ "Discurso em que se prova a vinda do Senhor Rei D. Sebastiāo", padre Antônio Vieira utiliza, como comprovação do que era crença geral no sebastianismo, o vaticínio de um outro célebre jesuíta, do século XVI: padre José de Anchieta. Este, no fatídico 20 de agosto de 1578, quando se encontrava em Pernambuco, teria sentido que se 'perdia' D. Sebastião no preciso momento do ocorrido e vaticinado que El-Rei retornaria a Portugal, reino que seria "uma fênix como o fora antigamente Roma, que senhoreou o mundo" (VIEIRA, 1998, p. 131-132). ${ }^{31}$ HERMANN, 1998, p. 220.

${ }^{32}$ Jacqueline Hermann chega a esboçar análise do "panegírico a São Sebastião" no livro No Reino do Desejado, fruto de sua tese de doutorado: cf HERMANN, 1998, p. 227-231. 
importância: a homonímia, que resulta em outra inescapável coincidência: Vieira profere o sermão no dia aniversário de D. Sebastião, que recebera tal nome em homenagem ao santo, como de costume. ${ }^{33}$ Ao lado da coincidência onomástica, o jesuíta procura aludir ao monarca de Avis por meio do epíteto que atribui a São Sebastião: 'o Encoberto', epíteto de origem céltica, aproveitado pelos sebastianistas para referir-se ao rei desaparecido na batalha de Alcácer Quibir. Outra palavra-chave pertencente a esse universo lexical sebástico empregada por padre Antônio Vieira é, aliás, 'batalha', que no sermão aparece em sentido metafórico para aludir à batalha literal, travada em 1578, nos areais do norte-africano. Leiamos este excerto do panegírico:

Assim saiu Sebastião daquela batalha, e assim foi achado depois dela; na opinião morto, mas na realidade vivo: opinione mortuum, vivum repertum. Atam a Sebastião a um tronco (escusada diligência para quem estava mais atado a Cristo, mais preso na sua fé, e mais seguro na sua constância), voam as setas, empregam-se os tiros, despejam-se as aljavas, desaparece o corpo, pregam-se já umas setas em outras setas: quem não crerá que está morto Sebastião? Assim o crêem os bárbaros, que já se retiram; assim o crê o tirano, que já está satisfeito; assim o choram os amigos; assim o lamenta a Igreja; assim o geme e suspira a Cristandade; mas que importa que Sebastião esteja morto na opinião, se estava vivo na realidade? ${ }^{34}$

Trata-se, portanto, de uma batalha no sentido de punição sofrida pelo santo romano, ou ainda de um confronto entre a santidade e a impiedade despótica e pagã por parte do imperador Diocleciano. No trecho em que comenta o caso de Jonas, Vieira vê na baleia que engole o personagem bíblico a imagem metafórica de uma 'ilha encoberta', à qual jamais se pode aportar. Com efeito, outro elemento da crença sebástica é a ilha encantada

${ }^{33} \mathrm{O}$ papa Gregório XIII presenteou D. Sebastião com uma das supostas flechas que teriam ferido São Sebastião. (cf MACCA e ALMEIDA, 2003, p.21) 34 VIEIRA, 1951, p.342. 
ou encoberta, onde D. Sebastião, após a derrota em Alcácer Quibir, ter-seia refugiado, aguardando o momento certo para retornar a Portugal..$^{35} \mathrm{O}$ panegírico sugere, pois, uma correspondência de Jonas, tido por morto pelos marinheiros ao avistarem-no ser engolido por uma baleia com (além, é claro, de São Sebastião) D. Sebastião, tido também por morto após agosto de 1578, mas, segundo criam alguns, na verdade vivo, escondido numa ilha encantada. Aliás, devemos observar que a imagem da ilha se associa muito enviesadamente ao contexto trazido pelo sermão referente à vida de São Sebastião, ajustando-se a associação muito mais adequadamente ao imaginário sebastianista, o que particularmente evidencia os propósitos sebastianistas por parte de Vieira.

Vejamos outra alusão ao monarca de Avis, a idéia que orienta todo o sermão: "Na opinião de todos era Sebastião morto: omnium opinione mortuum; mas na verdade e na realidade estava Sebastião vivo: vivum repertum" . ${ }^{36}$ (Em tal passagem, a própria lacuna da ausência do 'São', que antecederia o nome do santo romano, parece dar margem a se inserir no lugar o 'Dom' do título nobiliárquico do rei português.) A primeira circunstância é a mesma para ambos: assim como haviam acreditado estar São Sebastião morto após ser alvejado pelas flechas, acreditavam ter morrido $\mathrm{D}$. Sebastião na batalha de Alcácer Quibir. Dentro de uma linha lógica (mas também, na concepção hermenêutica cristã da época, linha histórica), existindo coincidência quanto à primeira circunstância, havê-la-ia quanto à segunda, isto é, assim como, na verdade e na realidade São Sebastião estivera vivo, na verdade e

35 João Lúcio de Azevedo, em $A$ evolução do sebastianismo, escreve: "Não deve ser muito anterior à Restauração [1640] a ideia da Ilha Encoberta, onde D. Sebastião se encontrava. D. João de Castro não alude a ela. Nesse tempo o monarca dos vaticínios vivia ainda a vida real. Esperavam-no de África, pelo estreito de Gibraltar. [...] com o correr dos anos a figura do rei se idealizou. A alguém ocorreu compará-lo ao rei Artur, cuja tradição se não perdera ainda. A semelhança era notável: idêntico o destino, D. Sebastião devia também ter a sua ilha." (AZEVEDO, 1947, p. 95-96)

36 VIEIRA, 1951, p. 342. 
na realidade estava vivo D. Sebastião. Mas e quanto ao fato de São Sebastião ter sido espancado até à morte (dessa vez, efetiva), quando apareceu perante Diocleciano, depois de o terem tido por morto, alvejado que fora por flechas? Lembremos que Vieira também reputa essa morte física de aparente, uma vez que a vida santa (como a de Abraão, Isaac e Jacó, citados pelo jesuíta como exemplos) nem com a morte física termina. Aqui não se trata propriamente de um contorcionismo conceptista, mas de um processo hermenêutico-alegórico cristão, onde há "uma 'semântica' de realidades reveladas pelas coisas representadas pelas palavras, não importam sejam palavras de sentido próprio ou figurado", ${ }^{37}$ o que permite vida espiritual post-mortem e vida espiritual e carnal se confundirem, assim não se contradizendo o retorno em carne e osso de D. Sebastião.

Mais acima dissemos que a metáfora da ilha relacionada à baleia que engolira Jonas pouco se associava ao santo romano e muito mais às crenças sebastianistas. O mesmo ocorre com o caso do corpo de José não visto por seu pai, Jacó, o que, conforme o entendimento do sermonista, constituiria evidência contrária à suposição de que José morrera. No caso de São Sebastião, não há sumiço de seu corpo; mas, como sabemos, o corpo de D. Sebastiāo jamais fora encontrado, fato que deu margem a dúvidas relativas à morte do monarca e condicionou o surgimento do sebastianismo. Eis uma das razões utilizadas por padre Antônio Vieira, no "Discurso em que se prova a vinda do Senhor Rei D. Sebastião", para atestar a sobrevivência dele à batalha de Alcácer Quibir: “[...] se morreu na batalha, como não acharam os mouros o despojo que tanto procuravam?"38 Essa razão se conjuga no referido "Discurso que prova..." com uma conjectura, a de que a Deus nada é impossível, inclusive Ele poderia permitir que um homem chegasse aos 300 anos. Tenhamos em mente que, no momento da pregação do panegírico aqui analisado (20 de agosto de 1634), D. Sebastião - se vivo - contaria exatos 80 anos, idade avançadíssima para a expectativa de vida da época.

37 HANSEN, 2006, p. 92.

38 VIEIRA, 1998, p. 113. 
Destaco ainda uma terceira associação que se percebe muito mais próxima de D. Sebastião (tal qual crido pelo sebastianismo) do que de S. Sebastião - expressiva evidência dos intuitos sebastianistas do sermão. José, depois de sofrer diversos tormentos no Egito, Vieira conta-nos:

Mas como Deus o tinha escolhido e reservado para restaurador do mundo: Vocavit eum lingua aegyptiaca, salvatorem mundi; o mesmo Deus o libertou das prisões; o mesmo Deus o resgatou da venda; o mesmo Deus o libertou da servidão; o mesmo Deus o revestiu de outra melhor púrpura: Vestivit eum stola byssina, et collo torquem auream circumposuit; o mesmo Deus o levantou ao trono de Faraó com majestade e poder universal: Constitui te super omnem terram Aegypti, para ser adorado, para ser reverenciado, e para ser conhecido e obedecido de todos: ut omnes coram eo geneflucterent, et propositum esse scirent universae terrae. Eis aqui quão diferente era a opinião, e quão diversa a realidade a respeito da vida e morte de José; mas como a Providência Divina tinha determinado que ele estivesse tantos anos encoberto sem saberem dele os de sua casa nem os de sua nação, oculta-se a realidade debaixo da opinião da morte, que é o que sucedeu hoje ao nosso encoberto. ${ }^{39}$

Devemos notar que o santo romano, 'o nosso encoberto de hoje', todavia, não era propriamente um predestinado a restaurar o mundo, como o fora José e como acreditavam os sebastianistas que o fosse D. Sebastião. Em passagem do "Discurso que prova...", Antônio Vieira transcreve vaticínios atribuídos a José de Anchieta sobre os acontecimentos posteriores ao retorno do monarca de Avis:

El-Rei D. Sebastião havia de passar três vezes a África, e a havia de ganhar e conquistar, e muita parte da sua gente mourisca havia de receber o sagrado batismo, pedido por ela de sua livre vontade, e que tomaria a cidade de Alexandria, onde se tomariam grandes riquezas, e que destruiria a casa de Meca, da qual não ficaria memória, e que conquistaria toda a Palestina, Antióquia,

${ }^{39}$ VIEIRA, 1951, p. 345. 
Jerusalém, e todo o império do turco, em que se tomariam grandes riquezas, e que conquistaria o império de Alemanha, por reinar nele imperador herege, e que seria Portugal uma ave fênix como o fora antigamente Roma, que senhoreou o mundo, e que o príncipe seu filho conquistaria toda a Ásia, e seria senhor de todo o mundo, porque tudo isto estava ordenado pelo Senhor, e que El-Rei D. Sebastião era um santo rei, pelo que o guardava Deus, para por ele obrar tudo o que fica dito. ${ }^{40}$

Portugal, "a nova fênix", que conquista o mundo tal qual o fizera antes Roma - esta que edificara o entendido como Quarto Império - finalmente, com o retorno redentor de D. Sebastião, consumar-se-ia como o Quinto Império, instituindo uma era de prosperidade nacional e mundial (pelo menos no que se refere aos valores cristãos), anunciada simbolicamente nos sonhos de Nabucodonosor interpretados por Daniel e reinterpretados pela hermenêutica místico-nacionalista lusitana. Nota-se que o sebastianismo não perdia de vista o dilatar a fé e o império, um no outro integrados e indissociáveis, conforme a vontade de Cristo revelada no Milagre de Ourique. Desse modo, o período de misérias vivido pelo reino português - período da União Ibérica em que Vieira profere o panegírico - encobre uma bem-aventurança nacional não aparente, mas verdadeira, enquanto D. Sebastião passa "tantos anos encoberto sem saberem dele os de sua casa nem os de sua nação”, igualmente ao que acontecera com José. A pobreza, as lágrimas, a fome e a sede, as perseguições e o ódio que acometem os bemaventurados (referidos no Evangelho de São Lucas, ponto de partida do sermão) significam também a usurpação da coroa portuguesa pelos Filipes espanhóis, os ataques dos hereges (protestantes) holandeses ao litoral brasileiro, a alta tributação imposta pelo governo filipino ao reino português; mazelas que escondiam a bem-aventurança de Portugal, a ser redimido pelo rei "reservado para restaurador do mundo". Isso posto, compreende-se melhor o pedido a São (Dom) Sebastião com que Vieira conclui o panegírico:

${ }^{40}$ VIEIRA, 1998, p. 131-132. 
[...] vereis pobrezas e misérias, que se não remedeiam; vereis ódios e desuniões que se não pacificam. Ó como serão ditosos e remediados os pobres, se vós lhes acudirdes: Beati pauperes! Ó como serão ditosos e aliviados os aflitos, se vós os consolardes: Beati qui lugent! Ó como serão ditosos e satisfeitos os famintos, se vós os enriquecerdes: Beati qui nunc esuritisi! Ó como serão contentes os odiados e desunidos, se vós os concordades: Beati estis cum vos oderint homines! Desta maneira, Santo glorioso, por meio de vosso amparo conseguiremos a bem-aventurança encoberta desta vida, até que por meio da vossa intercessão alcancemos a bemaventurança descoberta da outra: Ad quam nos perducat, etc.

Nessa concepção político-cristã, segundo esclarece Alcir Pécora, "Os desastres de Portugal, que Antonio Vieira nunca deixa de reconhecer e apontar, são, para ele, atos com que a Providência lembra aos portugueses o seu compromisso apostólico na eleição", além do fato de que "caberia ver nessas catástrofes um propósito purgativo e (em se tratando de cristãos, e não de gregos que os figuram) purificador, capaz de renovar o corpo místico nacional". ${ }^{41}$

A estratégia discursiva com que padre Antônio Vieira procura aludir a D. Sebastião no panegírico ao santo romano deriva, como vimos, de jogos retóricos amplamente empregados no seiscentismo luso-brasileiro e tem, segundo Margarida Vieira Mendes, origem na Idade Média; trata-se de uma "prophetical reversibility", ${ }^{42}$ que, nas palavras dessa autora, "has aesthetic consequences, for it shapes the form or the structures the texts" ${ }^{43}$ Com isso: "The name Sebastiāo, as it amphibologically designates the saint and the Portuguese king". ${ }^{44}$ A questão, de fato, não é meramente de codificação, isto é, grosso modo, onde se escreve no panegírico 'São Sebastiâo' quer-se dizer 'D. Sebastião'. A partir de um processo alegórico-

41 PÉCORA, 1994, p. 247.

${ }^{42}$ MENDES, 1999, p. 61-62.

43 MENDES, 1999, p. 62.

${ }^{44}$ MENDES, 1999, p. 62. 
hermêutico, os fatos narrados relativos ao santo romano são compreendidos como prefiguração do que acontecerá com o rei português. Assim, parafraseando Vieira: Quem é Cristo senão ele mesmo? Quem é Diocleciano senão os Filipes de Espanha? Quem é S. Sebastião senão D. Sebastiāo? Nessa lógica, padre Antônio Vieira, ao mesmo tempo em que encobre suas convicções sebastianistas face a uma possível reprimenda do governo filipino, estabelecido em virtude da morte/desaparecimento do monarca da dinastia de Avis, revela a veracidade da crença sebástica: a aparente morte do santo romano é a aparente morte do monarca de Avis. E mais: nessa espécie de equivalência entre o santo e o rei, expressa-se a própria concepção de que, para Vieira e sua época, estado e religião não se separam; o estado é juntamente corpo político e corpo místico.

Se o jesuíta lisboeta, a partir do momento em que tem a notícia do fim da União Ibérica e do início do governo da dinastia portuguesa bragantina, em 1640, abandona suas crenças sebásticas, ${ }^{45}$ pode-se dizer que esse abandono quase se atém ao âmbito da identidade do 'encoberto', que então passa a ser o primeiro rei da nova casa dinástica: D. João IV. Esse sebastianismo sem D. Sebastião, mas nem tão sem necessidade de encobrimentos discursivos, é que conduzirá Vieira tanto a se lançar a realizar ambicioso projeto de obra profética (a Clavis Prophetarum ${ }^{46}$ ) e a ter profícua

${ }^{45}$ Em famosa carta, intitulada "Esperanças de Portugal”, remetida ao Bispo do Japão e datada de 29 de abril de 1659, padre Antônio Vieira escreve: "[...] só digo a vossa senhoria que o Bandarra não falou uma só palavra em El-Rei D. Sebastião, antes todas as suas desfazem esta esperança; porque o rei que descreve é todo composto de propriedades contrárias que implicam totalmente com El-Rei D. Sebastiāo [...].” (VIEIRA, 1998, p. 102) Talvez haja menos contradição que coerência quando cotejamos esta carta com o "Discurso em que prova...", escrito não antes de 1633 e não depois de 1641, e notamos que nesse texto de Vieira, não aparecem as trovas de Bandarra nem sequer o nome do famoso Sapateiro quinhentista.

${ }^{46}$ Para Vieira, aliás, sua grande realização profético-literária seria a Clavis Prophetarum (por ele comparada em certa carta a "palácios altíssimos"), e não os sermões (na sua comparação, apenas "choupanas"). (cf VIEIRA apud PELOSO, 2007, p. 96) 
atuação no âmbito político-diplomático e econômico junto ao reinado de D. João VI quanto a ser acusado pela Inquisição de expressar crenças heréticas.

\section{Referências bibliográficas}

AUERBACH, Erich. São Francisco de Assis na Comédia de Dante. In: Figura. São Paulo: Ática, 1997. p. 65-80.

AZEVEDO, João Lúcio de. Evolução do sebastianismo. 2. ed. Lisboa: Clássica, 1947.

BÍBLIA SAGRADA. Brasília: Sociedade Bíblica do Brasil, 1969.

CIDADE, Hernâni; SELVAGEM, Carlos. O Sebastianismo. In: Cultura Portuguesa. Lisboa: Empresa Nacional de Publicidade, 1972. p. 129-138.

FRANÇA, Eduardo d'Oliveira. Portugal na época da Restauração. São Paulo: Hucitec, 1997.

HANSEN, João Adolfo. Alegoria: construção e interpretação da metáfora. Campinas: Hedra, 2006.

HERMANN, Jacqueline. No Reino do Desejado: a construção do sebastianismo em Portugal - séculos XVI e XVII. São Paulo: Companhia das Letras, 1998. LOURENÇO, Eduardo. Mitologia da Saudade. São Paulo: Companhia das Letras, 1999.

MACCA, Marcelo; ALMEIDA, Andréa Vilela de. São Sebastiāo: protetor contra guerras e epidemias. São Paulo: Planeta, 2003.

MENDES, Margarida Vieira. Baroque literature revised and revisited. In: TAMEN, Miguel e BUESCU, Helena C. (Org.). A revisionary History of Portuguese Literature. Nova Iorque e Londres: Garland, 1999. p. 58-78.

PÉCORA, Alcir. Teatro do Sacramento: a unidade teológico-retórico-política dos sermões de Antonio Vieira. São Paulo: Edusp, 1994.

PELOSO, Silvano. Antônio Vieira e o Império Universal: a Clavis Prophetarum e os documentos inquisitoriais. Rio de Janeiro: De Letras, 2007. 
PESSOA, Fernando. Sobre Portugal: introdução ao problema nacional. Lisboa: Ática, 1978.

SERRÃO, Joel. Do sebastianismo ao socialismo em Portugal. 3. ed. Lisboa: Livros Horizonte, 1973.

VIEIRA, Antônio. De Profecia e Inquisição. Brasília: Senado Federal, 1998. VIEIRA, António. Sermões. v. VI. Porto: Lello \& Irmão, 1951.

\section{Resumo}

Durante sua primeira residência no Brasil, de 1616 a 1641 (período praticamente todo inserido dentro da ocorrência da União Ibérica), padre Antônio Vieira expressou crenças sebastianistas em importantes textos, como o "Discurso em que se prova a vinda do Senhor Rei D. Sebastião". Essas crenças, que apenas deixarão de existir na obra do jesuíta lisboeta depois da Restauração, marcam o "sermão a São Sebastião" de forma especial: não explicitamente, mas sempre alusivamente. Neste artigo, analisamos as estratégias discursivas por meio das quais se insinua o sebastianismo no referido sermão, pregado na Bahia, em 1634.

\section{Résumé}

Pendant son premier séjour en Brésil, qui a duré de 1616 à 1641 (période presque complètement située dans l'Union Ibérique), le père Antônio Vieira a exprimé des croyances sebastianistes dans des textes importantes comme, par exemple, "Discurso em que se prova a vinda do Senhor Rei D. Sebastião". Ces croyances-ci, lesquelles on ne trouve plus chez Vieira après la Restauration, marquent le "sermão a São Sebastiāo" de maniére spéciale: non explicitement, mais toujours allusivement. Cet article analyse les stratégies discoursives avec lesquelles le sébastianisme s'insinue dans le sermon prêché à Bahia en 1634 et rapporté ci-dessus. 